\title{
Work from home: a boon in the phase of pandemic?
}

\author{
Anand.N. ${ }^{a}$, Raghuvanshi.R. ${ }^{b}$ \\ ${ }^{a}$ Amity Business School, Amity University Uttar Pradesh, Lucknow, India \\ ${ }^{\mathbf{b}}$ Assistant Professor,Amity Business School, Amity University Uttar Pradesh, Lucknow, India \\ a namrataanand55@gmail.com, ${ }^{\mathrm{b}}$ rraghuvanshi@lko.amity.edu
}

Article History: Received: 10 November 2020; Revised 12 January 2021 Accepted: 27 January 2021; Published online: 5 April 2021

\begin{abstract}
In this phase of pandemic and lockdown, where people are trying to cope up with stress along with their personal and professional responsibilities; do work from home acts as a boon to them? Flexible working arrangement enables the employees to avoid daily commutes and work according to their convenience but in this pandemic situation where people are bound to isolate themselves with their family, is flexible working helping them?

Previously, there was a mindset that an efficient workforce can be developed through a proper work environment and team work but after this pandemic, a new mode of working has replaced the traditional one. At present, 'work smart' has replaced 'work hard' by accepting and incorporating employees' multiple demands related to work and health, family and responsibilities, time and place. Work from home is one of the Flexible working arrangements provided by the employers to employees; also emerged as the "new normal strategy" after this pandemic. The IOT (Internet of Things) became essential for organizations to pace up the work. However, with digital platforms and up gradation of technology, the firms and organizations stay connected with their employees.

This study is descriptive in nature and it focuses on both the pros and cons of flexible working along with its effect on the employees' well-being and overall organizational work culture and productivity.
\end{abstract}

Keywords: Work life balance, Flexible working arrangement policy, flexibility in working, IOT (Internet of Things).

\section{Introduction}

The COVID-19 pandemic also known as novel corona virus is the greatest challenge we are facing in this decade. This pandemic phase was never imagined or faced before so the consequences are real as people are facing challenges physically and mentally as well. This virus has already caused innumerable deaths and fall down in economies globally. Due to the lockdown and continuous increase in cases, millions of people have lost their job and livelihood as they are unable to feed themselves and their families. However, adhering to workplace safety and health practices, the business houses and organizations adopted flexi policies and provided online platform to the potential employees so that the operations can be maintained. Flexi policies were already practiced before in IT companies at some places. Work from home, part time arrangement, job sharing and flexi hours are some of the common flexible working arrangements practiced in our India.

With the changes in workforce demographics, workplace flexibility has become an urge that should be fulfilled by the employers. Nowadays, women participate equally in a family and they prioritize their career over anything else. However most of the employees are from dual-earner families and many adults prefer additional education or personal interests outside the work, even workers who are on the edge of their retirement wants to seek work out of their occupation rather than completely retirement (Cahill, Giandrea, \& Quinn, 2014; Council of Economic Advisers, 2014). For instance, the Society for Human Resource Management recently surveyed over 400 employees to analyse employee benefits and founded that $60 \%$ of companies reported offering some type of telecommuting (with $22 \%$ offering full-time telecommuting), 54\% reported flextime, $31 \%$ reported offering compressed work weeks, and $10 \%$ said they offered job sharing (Society for Human Resource Management, 2015).

Chen.Y. \& Fulmer.I.S.(2018) examined and founded that FWAs result in several positive outcomes, such as higher job satisfaction, higher commitment, higher productivity and fewer work-life conflicts. Further some negative points are also analyzed such as more work-life conflicts and potential career penalties.

Basically, an employee might have positive or negative outcomes but here we have founded that more positive outcomes are witnessed rather than negative. So what are the employees' perceptions towards FWAs and how is it affecting their well-being and productivity as a whole. In the Management literature, there are two main attitudes of employees that represent their job attitude towards the work, job satisfaction and organizational commitment 
(Harrison, Newman \& Roth, 2006). Generally, job satisfaction means an emotional state resulting from one's job experiences (Locke, 1976), and organizational commitment is defined as the shared values and beliefs among employee and organization as a whole (Meyer \& Allen, 1991). Thus, the policies of an organization may vary and impact the employees differently but an ideal organization is one which increases both the phases of an employee i.e. job satisfaction and organizational commitment.

Although, there is no such universal definition for FWA but it has been defined as flexibility in job about where one works and when one works, as well as how much one works (Council of Economic Advisers, 2014). As per signaling and social exchange theories, employees who comprehends that they have FWAs available and who feel supported and valued by the organization respond to these signal with more favorable evaluation of their jobs and they reciprocate with more enthusiasm and enhanced feelings of commitment to the organization and its objectives (Blau, 1954; Casper \& Harris, 2008; Rhoades \& Eisberger, 2002).

\section{A. FWA in IT organisations before COVID-19 in India}

Information Technology (IT) is the fastest growing sector at global level. In India, IT contributes 16\% of GDP and is the most demanding and fastest growing industry. India has been globally recognized as a Research and Innovation hub. Incidentally, IT has been emerged as the fastest growing industry in India creating scope and opportunities for innovative ventures and wider employment opportunities. It is now considered as the powerhouse of technology. With the increase of employment opportunities, business tends to focus on employment issues as well. The demanding diversified work force and work culture results in deviations and issues among employees. Therefore, organizations seek help from their HR managers to adopt such policies that can help employees to concentrate and work efficiently and effectively. Business houses have been dragged into international market environment after liberalization and globalization. Thus, they have been exposed to increasing competition in the market as well.

With the increasing competition, business faces more challenges and thus to overcome, they need to adopt such innovative ways for their long term survival that can help them in optimizing productivity and maintain sustainability and growth. FWA is among one of those innovative techniques of HR management that has already been adopted by the IT sector. There is a positive influence of FWA on the organisations such as reduction in employment turnover, decrease in rate of absenteeism, improved employee morale, increased employees involvement (EI) and increase in employee commitment towards the organisation. The HR strategy of adopting FWA mainly focuses on optimizing deployment of employees and providing flexibility at workplace (Hill et, al., 2001).FWA is an employee benefit incentive provided by employer to employee for motivating them to control over their time and place so that they can work beyond the normal working hours (Hill et, al., 2003). The previous findings of studies related to HR matters in the IT sector shows that the concept of psychology has received much attention within the work psychology to understand the organisational and individual relationship (Guest \& Conway et, al., 2002). The work environment puts a great impact on the morale of employees, their engagement and productivity being negatively and positively. Previously, changes in lifestyle, work/life balance, fitness and health were not considered as the major factors of being advantageous but now these factors are considered as the basic concerns of the workers and majority of the companies admire this. Companies attempt various such practices that can motivate employees such as agreements to security of employment, salary based performance, assisting in balancing work and family and also implementing different modes of sharing information. From large to small, IBM to McDonalds, flexibility in working has become the buzzword; it has been observed that well established companies adopt and promote flexible working arrangements for their employees to make them feel valued. Big firms and corporate houses proudly exhibit about their telecommuting and flexible work hour practices. However, the reality is that these new firms with such practices have been emerged as the true champions of flexibility. Further, some managers have felt opposite and considered FWA not so satisfying in terms of productivity. Here are some of its limitations as well:

- If employees do their work sincerely at home or not.

- What if they are wasting time chatting and scrolling social media?

- They doubt the employees about if they are outsourcing the work or doing it by their own.

It has been observed that flexibility in working inspires creativity and innovation resulting in enhanced productivity; however it bring challenges also based on the organization's stage of life cycle. It differs accordingly among employees and employers. Some employers do not found flexibility suitable for their organization; on the other hand employees' value flexibility the most; even more than their benefits and perquisites. However, it is important to recognize the specific needs and preferences of different employee segments. Every firm has few dependable, loyal and committed employees, they may not be stars but their commitment makes their impact and so it is necessary that these employees should be made role models. This helps in motivating and mentoring employees to enhance discipline and productivity. 
Recently, an article from Economic times highlighted some of these advantages such as improved employee productivity, increased retention and work motivation resulting from flexible working arrangements. For an employee, it is a signal that firms not only recognizes their contribution to work but also is aware of their needs and aspirations which actually motivate them to work efficiently and remain committed to the organization. All the firms are running a race to become success and are consistently trying to increase their profitability and productivity by introducing flexibility into their firm.

\section{B. Types of flexible working arrangements}

The IT companies, for instance "Accenture" implemented various such flexi policies such as Flexi time schedule, Fly backs, telecommuting, job sharing, part time arrangement and client side flexi work and extended home location.

Flexi work schedule: under this, the employees can work according to their convenience without disturbing their regular working hours. For instance, employees can work fewer than five days or change start and end timings.

Part-time arrangement: it is the arrangement in which employees work for reduced hours per normal working day or fewer days in standard week. The reduced work load is designed in such a way that it compensates the total number of working hours.

Job-sharing arrangement: under this, the work is distributed between two part-time employees to complete the total working hours.

Fly backs: this is an arrangement that offers an employee to fly back home from office location. It helps an employee to improve their work life balance.

Client-site flexi work: it is provided to those employees who work at client site for long hours and all their needs are fulfilled to balance their work and personal life.

Telecommuting/ working from home: this is an arrangement that enables the employees to work from home away from office. It helps in reducing stress, time and costs including fixed office spaces.

Full week at home: this arrangement provides an opportunity to an employee to enjoy long weekend by starting their work from mid Monday to early Friday without disturbing the total number of working hours.

Extended weekends within home locations: under this the employee divide five-day work week and work four days near the project site and fifth day at home or some alternate location.

Extended home/ client location: under this arrangement an employee can change the timings of working hours by extending the period of time at the client site or at any other location without disturbing the standard working hours.

More than $80 \%$ of Indian companies have confirmed that their productivity is increased only due to flexibility. There has been a survey on 500 business manager that proves that productivity and flexibility are proportional to each other and related somehow. Almost $84 \%$ of New Delhi's senior managers believe that increase in firm's productivity is due to flexi policies. 77\% Mumbai and 74\% of senior managers in Pune has the same belief.

There are some other findings as well from different IT sectors from all over the India supporting flexi policies as follows:

- $\quad 87 \%$ respondents from Bangalore declared flexibility in their firm in terms of time and location

- $\quad 88 \%$ respondents from Hyderabad confirmed that their firm's productivity is directly proportional to firm's flexibility

- Nearly $84 \%$ of New Delhi respondents declared that flexi policies has improved their productivity

- More than $92 \%$ of Pune respondents confirmed that most of the employees prefer to go part-time during their job tenure.

Today, when we all are facing challenges due to the COVID-19 pandemic, FWAs has emerged as the 'new normal' policy for organizations. Now, every organization has adopted this strategy and has provided this option to all their employees so that they can work from home with proper safety measures.

\section{Objectives}

The purpose of this study is to illuminate the importance of flexible working arrangements in IT companies during COVID-19 pandemic in India. There are mainly 3 objectives of this study as follows:

- $\quad$ To understand the impact of FWAs on the employees' perception and well-being during COVID-19. 
- To analyze the employees' job attitude towards the organization while working from home during COVID-19.

- To investigate the overall impact of FWAs on the organizational work culture and productivity during COVID-19.

\section{Research Methodology}

This study is descriptive in nature as it is an accumulation of data from different sources such as case studies, journals, research papers, Google and newspapers. This study is the analysis about if work from home is a blessing for the employees during this pandemic or not. It examines the different aspects of flexible policies arranged in an organisation and provided to the employees to maintain their work life balance. Due to the limited access and pandemic situation, it was difficult to gather primary data. Hence, secondary data is used and conclusions are drawn with limitations and discussions.

\section{Findings And Discussions}

Now coming to the present situation of the COVID-19 pandemic, flexi policies has emerged as the 'new normal' for organizations and employees. Flexible working arrangements helped the companies to continue their production online from remote locations. Although, our economy has been affected due to the shut-down of factories and manual production but services are being provided through internet like customer support, IT services, online studies. The IOT (Internet of Things) plays an important role in adopting such practices and so IT sector is the one which acts as a saviour at this time. Before COVID-19, flexi policies were not so much in use but the companies who were already practicing these policies are not so affected; on the other hand, the companies with no such policies had to face challenges at the beginning.

According to RGF international Recruitment's latest Talent in Asia Report 2020, employers want to continue flexible working arrangements even beyond the pandemic. Previously, flexible working arrangements were not so popular in India but $93 \%$ of employers have since supported the option, and $61 \%$ intended to continue with them, that was more than that of Indonesia (47\%), Vietnam (55\%) and Greater China (47\%). This report is based on a comprehensive study of over 4,600 survey responses related to hiring trends across 11 Asian countries and markets. Now, employers in India are quickly adopting digital solutions to remove barriers coming in their way among which $63 \%$ of them do frequent video calls to keep their staff motivated, and $48 \%$ of companies accelerated online interviews.

As per the study, remote working options have not seen a huge decrease in productivity. However, it has been observed that only $14 \%$ of employers reported less than $50 \%$ productivity, while $14 \%$ have reported higher than their usual productivity rates. These rates are good for companies that plan to continue flexible policies, and also for the employees who consider flexible working hours (66\%) and remote working (65\%) to be the most important factors to maintain balance among their work and family.

The outbreak of COVID-19 pandemic has tremendously affected the global economy by damaging the business houses across diversified sectors around the globe. Comparatively, India is less affected than other countries but has a great impact on the country's economy and business houses. According to the Economic times, latest report represents that there is a revenue drop expected by $6 \%$ in TCS, 5\% in Infosys and $9 \%$ in Tech Mahindra. As per analyst, Indian IT firms will be impacted due to this COVID-19 induced lockdown in US and Europe as it is expected that clients would cancel to spend on technologies and so would affect the overall revenue.

Shetty.D (2020) analyzed the flexible arrangements and shared some incidents to understand the pros and cons of working from home. Comparatively, work from home for IT sector was more familiar than other sectors. Working from home has been described as the very attractive and helpful for professionals as they can eat homecooked meals, save their time and money on daily commutes and spend time with their loved ones. According to a veteran software engineer, a company can save its real state expenses by offering its most of the people an opportunity to work from home. However, he also mentioned the dark side of this suggestion such as data security and client privacy issues. Further, working from home has been recognized as a taboo for some situations but it is believed that employees working from home are not as committed to the work as they tend to be working in office. Secondly employers doubt that whether employees are stick to their job or not like what if they have started doing some another part-time job or taken up freelance assignments. Finally, the companies work culture gets affected. The business houses invest a lot of effort and time to create a work culture that stimulates its employees to work with full zeal and enthusiasm. It contributes as a motivating factor to the employees; that cannot be created or sustained among the employees working from home.

Courtney. E. (2020) explained this impact in America through a remote work statistics and identified some intriguing facts as follows: 
a) Remote working is here to stay for long: As per the Gartner Survey of company leaders it has been founded that $80 \%$ of them have planned to provide remote working access to their employees for at least part of the time after this pandemic, on the other hand $47 \%$ of them will allow full time work from home facility to their employees post- pandemic.the Columns icon from the MS Word Standard toolbar and then select the correct number of columns from the selection palette.

b) Remote working retains the talent: Recently, according to Flex job surveys $65 \%$ respondents' wants to be full time remote employees post pandemic. Further, $27 \%$ of workers are so much in favor of remote working that they can even take $10 \%$ to $20 \%$ pay cut to work remotely.

c) Remote working is beneficial for business: It has been founded through research that business loses $\$ 600$ billion per year to workplace distractions; on the other hand remote workers are found 35\% to 40\% more productive than their office employees. As per the performance-based remote work statistics in 2020, $94 \%$ of employers reported that productivity has been the same $(67 \%)$ or even higher $(27 \%)$ during this pandemic than before.

d) Remote working leads to job satisfaction: Despite of devastating year in 2020, remote workers reported increase in happiness index with 75 out of 100 as compared to 71 for in-office employees. Overall, there is a positive impact of remote working on employees rather that in-office working.

e) Remote working increases production: As per the Flex jobs' Survey, 95\% of respondents claimed that their productivity has been either increased or been same working from home. Further $51 \%$ of them have claimed being more productive when working from home and the reasons found for being more productive are as follows:

- $\quad$ Less interruptions

- Increased focus and concentration

- $\quad$ Peaceful work environment

- $\quad$ Organized and more comfortable workplace

- No politics and office distraction

f) Remote working is environment friendly: Due to reduction in traffic congestion and air pollution from commuting, the overall environment has been affected positively. The best part of this pandemic is the change in environments that have lead to slowed deforestation rates, reduced air pollution and improved quality of water and air all over the world.

\section{Conclusion}

After going through the literature review, case studies, latest reports and focused group discussion, this study concludes with the statement that FWA has positive influence on organization and its employees on a broader view. Before COVID-19, the survey finds that workers practicing flexi-working are much productive and happier and most of the companies introduced flexi policies to reduce cost and boost productivity and profitability. The trend was supposed to increase in near future because $80 \%$ of Indian companies directly linked their increasing revenues and productivity with flexible working.

Flexi policies have emerged as a savior at the time of this COVID-19 outbreak. According to the latest reports, it has been observed that productivity was not affected. Further, most of the tasks get accomplished virtually through technology such as hiring, on boarding, training, etc. Google announced work from home for the employees till June, 30, 2021 except those who are necessarily needed at the office. Amazon had already extended its WFH policy from October 2020 to January 2021.

However, working from home is not favorable for the long term but there must be such flexible policies present in the organization so that any disaster or pandemic cannot affect its working as a whole. The findings suggest that a company should always be ready with its HR team to overcome such issues and challenges in future and should be flexible enough to mould its strategies and policies accordingly. Further, FWA impacts positively on employees' perceptions and job attitudes. They feel valued and caring as their well-being and health are prioritized. On a broader view, FWA plays an important role in organizations. It provides flexibility, committed employees, higher productivity and reduced costs that result in sustainability and overall growth of the organization.

\section{References}

Chen.Y., \& Fulmer.I.S.(2018). Fine tuning about what we know about employees' experience with flexible work arrangements and their job attitude. Hum resour manag,57, 381-395.10.1002/hrm.21849

Kim.H., \& Gong.Y. (2017). Effects of work-family and family-work conflicts on flexible work arrangements demand: a gender role perspective. International journal of human resource management, 28(20), 29362956.https://doi.org.10.1080/09585192.2016.1164217 
AM.DS.B. (2020).Corona virus (COVID-19). Asia- Pacific Journal of Health Management, 15(1):i371.DOI 10.24083/apjhm.v15i1.371

Mathur.R.(2020). COVID-19- How should employers in India respond, recover and restore? People matters.https://www.willstowerswatson.com/en-IN/Insights/2020/03/covid-19-how-should-employersinindia-respond-recover-and-restore

Pandey.M. (2020). The impact of pandemic COVID-19 in workplace. European Journal of Business and Management, 12(15). 10.7176/EJBM/12-15-02

Hariharan. S. (2019, February 12). Flexible working arrangement is top priority for today's workforce, survey finds. The times of India. https://timesofindia.indiatimes.com/toireporter/author-SindhuHariharan479238145.cms

Rahman.M.F.W, Surjanti.J., \& Kistyanto. A. (2020). Flexible work arrangements in COVID-19 pandemic era, influence employee performance: the mediating roleof innovative work behaviour. International Journal of Management Innovation \& Entrepreneurial Research,6(2), 10-22. https://doi.org/10.18510/ijmier.2020.622

Study of Flexible Work on organizational Performance, chapter-3, (1-81) https://shodhganga.inflibnet.ac.in/bitstream/10603/54578/11/11_chapter\%203.pdf

Shagvaliyeva.S.\&Yazdanifard. R. (2014). Impact of flexible working hours on work-life balance. American Journal of Industrial and Business Management, 4, 20-23.http://dx.doi.org/10.4236/ajibm.2014.41004

Shockley. K.M.\& Allen. T.D. (2012). Motives for flexible work arrangement use. Community, work \& family, 15(2), 217-231.https://dx.doi.org/10.1080/133668803.2011.609661

Kumar.V. (2020). Covid-19 and its impact on the Indian IT Industry. Industry wired. https://industrywired.com/covid-19-and-its-impact-on-the-indian-it-industry/

Shetty.D. (2020, May 18). Work from home is nice, but the office wants you back. The Hindu. https://www.thehindu.com/business/is-work-from-home-sustainable-for-the-long-run-during-thecoronaviruspandemic-for-the-rest-of-india/article31614488.ece

Courtney.E. (2020, Dec 21). Remote work statistics: Navigating the new normal. Flexjobs. https://www.flexjobs.com/blog/post/remote-workstatistics/\#: :text=\%E2\%80\%93\%20Remote $\% 20$ Work $\% 20$ Increases $\% 20 \mathrm{Job} \% 20$ Satisfaction\&text=And $\% 2 \mathrm{C}$ $\% 20$ remote $\% 20$ employees $\% 20$ are $\% 20$ more,question $\% 20$ related $\% 20$ to $\% 20$ job\%20satisfaction. 